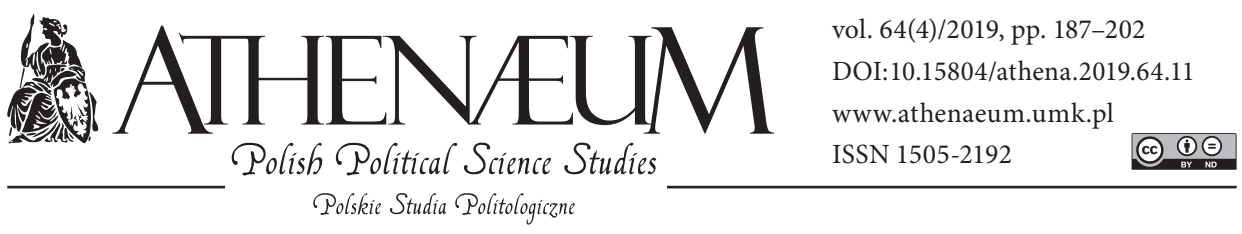

\title{
SWEDEN'S IMAGE POLICY IN THE TIMES OF REFUGEE CRISIS
}

\author{
POLITYKA WIZERUNKOWA SZWECJI W DOBIE KRYZYSU \\ MIGRACYJNEGO
}

\author{
Anna Kobierecka* ๔
}

\begin{abstract}
Sweden has a substantially long tradition of conducting an image policy using both public diplomacy and nation branding. The refugee crisis is a significant challenge for maintaining a strong nation brand and positive perceptions of this country, mostly owing to contradictions between the declared values of Sweden's image and nation brand and the real steps undertaken by the government to limit refugee immigration. The aim of this article is to discover potential correlation between the refugee crisis and changes within Sweden's image and the strategy for promoting the country abroad, as well as Sweden's methods and forms of international communication.
\end{abstract}

Keywords: Sweden; image policy; refugee crisis; nation branding; public diplomacy
Szwecja posiada stosunkowo długą tradycję realizowania polityki wizerunkowej zarówno poprzez dyplomację publiczną, jak i branding narodowy. Kryzys migracyjny stanowi istotne wyzwanie dla utrzymania silnej marki narodowej oraz pozytywnego postrzegania tego kraju na arenie międzynarodowej, głównie ze względu na przeciwności, jakie pojawiają się między założeniami przyświecającymi kreowaniu marki narodowej i wizerunku Szwecji a realnymi działaniami podejmowanymi przez rząd w zakresie ograniczania napływu uchodźców. Celem artykułu jest znalezienie potencjalnego powiązania pomiędzy kryzysem migracyjnym a zmianami w wizerunku Szwecji oraz zmianami, jakie zachodzą w obrębie strategii promowania Szwecji poza jej granicami oraz metod i form komunikowania międzynarodowego.

Słowa kluczowe: Szwecja; polityka wizerunkowa; kryzys migracyjny; branding narodowy; dyplomacja publiczna

\footnotetext{
* University of Łódź, Faculty of International and Political Studies.
} 


\section{INTRODUCTION}

Since 2012, intensive migration flows in Europe have been observed mostly owing to local conflicts in North Africa, especially the civil war in Syria. In 2015, more than a million refugees reached Europe. In 2015 and 2016, around 1.3 million asylum applications from citizens of non-member countries were registered (Eurostat, 2017). Sweden was one of the most popular states among refugees, and at the peak of the refugee crisis in 2015 it received 162,877 firsttime asylum applications. This intensification of refugee inflow resulted in the introduction of temporary restrictions within Sweden's immigration and asylum policy (Ministry for Justice, 2017), and therefore a reduction in the numbers of refugees entering the country. In 2016 and 2017, the number of applications was reduced to only 28,939 and 25,666, respectively (Migrationsverket, 2017). Taking these numbers into consideration, as well as the legal changes introduced by the government, it is evident that the refugee crisis caused Sweden to react to new challenges to its international image and position caused by the intense influx of refugees.

The aim of this article is to investigate and analyze potential changes in Sweden's image policy and international communication strategy in light of the refugee crisis. The research is based on several research questions: Can we observe any changes within the image policy or communication strategy of Sweden that were caused by the refugee crisis? If any changes were made to Sweden's image policy and external communications, what are the main objectives of such changes?

\section{METHOD}

In order to find answers to the research questions listed above, an analysis of the most significant government documents was conducted. The selected documents included statements, information, and guidelines from the Ministry for Foreign Affairs, as well as documents and branding and promotional strategies from the Ministry for Justice. Documents from both the present and past were used. This allowed for the observation of changes in image policy and communication patterns. Additionally, in order to answer the question concerning potential changes in the perceptions of Sweden and its international position, an analysis of chosen branding and soft power rankings was conducted. The author decided 
to select the following four rankings: Nation Brands Index, Country RepTrak, The Good Country Index, and Soft Power 30, as these are some of the most recognizable and reputable rankings. Country Brand Index was not included due to the time frame - the last ranking encompasses the 2014-2015 period, and therefore it lacks the most current data that would allow us to assess the potential influence of the migration crisis. One of the most significant studies included in this analysis is the Swedish Institute's report concerning the influence of the refugee crisis on the image of Sweden.

\section{LITERATURE REVIEW}

Modern states notice the need to manage their international image, as positive perceptions of a state can contribute to the state reaching its political, economic, and cultural goals (Kaneva, 2011; Melissen, 2005; Dinnie, 2016). According to Peter van Ham (2001), having a bad reputation or none at all can be a serious handicap for a state that wishes to be significant in the international arena. Therefore, image and reputation became significant elements of state's strategies. In a globalized world there is no time for in-depth analysis of information, therefore perceptions of other states or nations are based mostly on clichés or stereotypes that shape opinions and influence decision-making process to much extent (Anholt, 2007). The main methods of image management are related to public diplomacy and nation branding. James Pamment outlines soft power concept and development communication encompassing development aid as well, when talking about politics of image (Pamment \& Wilkins, 2018). Both share the same goal - to promote a certain and desirable image of a state - though they have different origins and use different tools. Nation branding derives from marketing and serves mostly economic goals, while public diplomacy is mostly related to building cultural relations and serving political goals (Melissen, 2013). What is more, both branding and public diplomacy are complementary as they are both aimed at foreign publics and foreign perceptions are a base for their actions. Therefore, when nation branding and public diplomacy are used together, they can be perceived as complementary tools for managing a state's image and, through this, attracting other societies, companies, students, investors, etc., and enhancing a state's international position. Providing long term approach in both areas is one of the conditions of effective image management (Melissen, 2005). However, in case of branding strategies, when faced with unexpected 
circumstances, they can be perceived as an ad hoc tool of responding to potential challenges or threats.

We can identify many stakeholders engaged in promoting a certain vision of a state and engaged in conducting the image policy. Those are ministries, cultural institutions, agencies, trade boards and chambers, interest groups, NGOs and companies, just to name a few (Anholt, 2007). Image policy allows to coordinate their actions, at least to some extent, and create more coherent strategy of building state's image and reputation. The main difference between public diplomacy and nation branding is that the first is more about building and maintaining positive relations with other actors, while latter about projecting identity (Melissen, 2005).

The idea of soft power is inseparably related to nation branding and public diplomacy. The concept of soft power resources is widely defined by Joseph Nye (2004) and is significant in the light of the refugee crisis, as Sweden is one of the most popular destination countries among refugees. The core resources that are used in the branding of Sweden are convergent with the aspects attracting migrants - mostly related to social aspects and society in general, e.g., the welfare state, tolerance, egalitarianism, etc. Therefore, image management will be of extreme importance in the time of intensified migrations in Europe. In spite of an already established and well-functioning system of nation branding and public diplomacy, Sweden is facing new challenges concerning effective international communication, especially when it is willing to discourage rather than attract migrants. Such aspects of both nation branding and public diplomacy have not yet been well analyzed.

\section{IMAGE POLICY IN TIMES OF REFUGEE CRISIS}

Sweden has been building its international image since the interwar period, before the terms branding and public diplomacy were even used. However, the official branding of Sweden did not begin until the 1990s, when the Council for the Promotion of Sweden Abroad was established. It entered a new level when Simon Anholt and Mark Leonard engaged themselves in building Sweden's brand. Their work resulted in introducing the first Swedish brand platform built on the uniform Swedish identity and supported by regularly analyzing the image of Sweden. The strategy for the promotion of Sweden that was introduced in 2014 focused on displaying certain parts of the Swedish identity to make them 
the most influential and recognizable abroad. Additionally, a visual identity has been added to the branding strategy based on the national flag and colors as a strengthening factor (Söderhavet, 2014). The core areas of Swedish identity included society, innovation, sustainability, and creativity. Society is therefore presented abroad as based on human rights and equal opportunities and gender equality. Advanced welfare and broad social security are the aspects to be highlighted (Government Offices of Sweden, 2014). The core idea is to attract talent and investments through social security and stable economy, however, especially welfare state can work as an incentive for migrants and refugees. Other profile areas best describing and promoting Sweden are innovation, where Sweden is presented as one of the most innovative countries in the world with worldleading innovations within automotive industry, sustainability encompassing - among others - green buildings, battery driven vehicles, renewable energy use and characteristic bond between society and nature. Creativity is the last profile area. Here creative industries are listed, especially film, music, design and fashion (Government Offices of Sweden, 2014). From the perspective of refugee crisis, the society profile area seems to be of great significance as it encompasses characteristics of Swedish society that can attract migrants. The aim of promotion strategy was to create a consistent message concerning Sweden. The image which was supposed to be created with the use of strategy was exhibiting Sweden as an open and innovative society being a hub for innovation and co-creation. Creating such image of Sweden was significant for achieving political objectives, promoting trade, attracting investment, tourists and talent, and encouraging cultural and scientific exchange. All of these elements for the promotion of Sweden abroad have been sustained in the newest strategy, which was proposed in the middle of 2017, following the most intense period of the refugee crisis in Europe (Government Offices of Sweden, 2017a). Although theoretically the content of communicated areas and core values did not change, different dimensions of those were highlighted. Sweden is supposed to be communicated as development-oriented country and the Swedish model is showed more in terms of contributing to economic growth and stability as well as innovativeness rather than social security. Also the aims of the strategy changed slightly with the special focus on current challenges of negative rumors and outright information, especially concerning the aspects of migration and integration (Government Offices of Sweden, 2017a).

Since 2014 parliamentary elections, Sweden has been ruled by a center-left coalition with the dominant position of the Swedish Social Democratic Party 
(SAP), which declared its positive attitude towards refugees, appealing to human rights and moral responsibility. However, the third parliamentary party is the Sweden Democrats (SD), with social support reaching almost $20 \%$ in November 2015 (Statistiska Centralbyrån, 2016). The party of the Sweden Democrats is the only far-right and nationalist party in Sweden. Since the strategy for Sweden's brand is based on the idea of "Open Sweden", it came to no surprise that when migration started to intensify, Sweden, along with Germany, declared its openness and willingness to provide support for refugees. However, when the Swedish asylum system and integration system turned out to be unprepared and ineffective in the face of such an intense inflow of refugees, the government decided on a U-turn concerning Sweden's openness towards newcomers (Witte \& Faiola, 2016). Legal changes within immigration and asylum policies were introduced by the government, which seems to clash with the image policy of presenting Sweden as an open and tolerant country. Such dissonance can have a prominent influence on perceptions of Sweden abroad. The crisis of tolerance both in society and among politicians can be observed as the electorate of SD has grown along with the influx of refugees. Also, the government decided to initiate border controls and a restricted asylum policy, including, among other things, limiting the possibilities for achieving residence permits and using family reunification procedures. What is more, even Magdalena Andersson, the Minister for Finance, admitted that Sweden made a mistake by accepting so many refugees and that the integration system in Sweden is not functioning effectively (Olsson, 2017).

The threats to Sweden's image as an open country stemming from the refugee crisis are hard to ignore and are noticed in Sweden. In one of his studies, James Pamment interviewed senior advisors and heads of departments responsible for Sweden's image policy. One of the senior representatives of the Swedish Institute indicated that: "Sweden is no longer what the nation perceives itself to be; i.e. open, tolerant, and with strong focus on the right to asylum. Instead, we are perceived as closing our borders" (Pamment, Olofsson, Hjorth-Jenssen, 2017). Such a statement is evidence for the impact that the refugee crisis has on Sweden and its international image. Taking into consideration the importance attached to having a strong nation brand (www.se.se), at least some changes within the promotion strategy should be introduced in order to mitigate problems related to such dissonance between the written promotion and branding strategy and the actual actions of decision makers.

One of the means for softening the negative reception of legal changes within Sweden's asylum policy is to highlight other aspects of Swedish openness. 
Therefore, Sweden refused to change one of the core values that contribute to its identity and nation brand. Open Sweden is still an element in the construction of Sweden's image abroad, though it is used in different terms than before. The aspects of free trade, openness to innovativeness, and contributing to the creation of a global marketplace of ideas play a leading role in Sweden's current communication with the external environment, moving the focus away from welfare, tolerance, openness, and egalitarianism (Interview, 2017). The statement of a UD-KOM representative presented below seems to confirm this new communication strategy: "Naturally, in the situation that emerged, our government had to take certain decisions to control the situation, but that does not mean that our core values are not still there. There are other ways in which we are open [...] such as free trade [...]" (Pamment, Olofsson, Hjorth-Jenssen, 2017). After the migration crisis hit Europe, the image of Sweden changed. However, this change was not necessarily as significant as many may have expected. For instance, in two rankings measuring reputation and being a good country, Sweden's ranking dropped from first place to third and sixth place, while in the two following rankings its position did not change. The table below shows how Sweden's position changed during the migration crisis in the chosen rankings:

Table 1. Sweden's positions in chosen rankings 2015-2017

\begin{tabular}{|c|c|c|c|}
\hline Ranking & Position in 2015 & Position in 2016 & Position in 2017 \\
\hline Country RepTrak & 3 & 1 & 3 \\
\hline The Good Country Index & 6 & 1 & 6 \\
\hline Soft Power 30 & 9 & 9 & 9 \\
\hline Nation Brands Index & - & 10 & 10 \\
\hline
\end{tabular}

Source: Author's elaboration on the basis of chosen rankings.

In 2017, the Swedish Institute decided to conduct a survey concerning the image of Sweden after the migration crisis. In the survey, citizens of seven European countries (Norway, Denmark, Poland, Great Britain, Turkey, Germany, and Hungary) were interviewed and asked questions concerning, among other things, the perception of the Swedish migration policy, Swedish society, Sweden's handling of the migration crisis, and how the media talk about Sweden. The general perception of Swedish migration policy in the past several years as a result of the refugee crisis is not explicit. A large part of the respondents perceived Swedish attitude towards refugees as being open at first, but then restricted (37\%). The 
second largest group (32\%) thought that the Swedish migration policy was open during the whole migration crisis and that Sweden received large numbers of immigrants (Bilden av Sverige efter Flyktingkrisen, 2017). Therefore, the opinion concerning changes within the Swedish migration policy seems to be quite valid, as the migration crisis caused the introduction of some restrictions within its migration policy. The respondents were asked if their opinion on Swedish society have changed in the last two years, and more than half (64.4\%) declared no change in their perceptions. At the same time, the general opinion of Swedish society was rather good - nearly $70 \%$ of the respondents declared positive perceptions (indicating from 5 to 7 on the seven-score scale, where 7 equals 'very positive'). Changes in perceptions of Swedish society within the last two years were most positive among Germans and least positive among Norwegians (Bilden av Sverige efter Flyktingkrisen, 2017). When their similar attitude towards the refugee crisis is taken into consideration, the Germans' positive perception of Swedish society should not come as a surprise. In contrast, the Norwegian government is rather critical of Swedish migration policy, and its own migration policy is more restrictive (The Local, 2016).

The respondents were asked for their thoughts about the media reporting on Swedish society within the past two years, and $34 \%$ of them indicated the migrant crisis as one of the topics in the media influencing the image of Sweden. While immigration was listed in second place among the topics connected with media coverage, only half of the respondents referred to problems caused by immigration. The outcome of the Swedish Institute's report seems to contradict the interviews conducted by James Pamment. One of the interviewed representatives indicated that the media frequently reported about Sweden's method of dealing with the refugee crisis in a negative manner, often displaying Sweden on the verge of societal crisis as the result of an asylum policy that was too open (2017). Examples of such media behavior can be seen in articles tackling the phenomenon of sexual harassment during the youth music festival in Stockholm (Sveriges Radio, 2016) or Donald Trump's statement regarding the open asylum policy in Europe and terrorist attacks, suggesting that even Sweden has such problems (Chan, 2017).

Dealing with disinformation in the international media could be a serious challenge for the Swedish institutions responsible for managing the nation brand or image in general. In dealing with this problem, the opinion of the Minister for Justice, Morgan Johansson, which was published in The Wall Street Journal in March 2017, can be considered. He spoke, among other things, about the incor- 
rect opinion of Sweden as a country with a high level of crime deriving from a large amount of asylum immigration and associated with the political discourse of the Sweden Democrats Party. He also added: "Sweden has given protection to 143,000 Syrian men, women and children since 2011. We are proud of that, because many of these people might otherwise have perished in Homs or Aleppo. Now these people must get a good start in Sweden. The number of jobs has increased by more than 150,000 since 2014 . Unemployment has fallen, growth is high and our public finances are sound" (Government Offices of Sweden, 2017b).

In order to tackle the problem of misinformation in the media, significant changes within the external communication of Sweden were introduced, such as establishing a task force devoted to coordinating migration, including informative and communicative activities. The idea was to provide objective information concerning current legal solutions within the migration and asylum policies. Starting in June 2016, the websites of the Ministry for Foreign Affairs, social media channels, and embassies transmitted targeted messages. The targeted groups are people planning to travel to Sweden as asylum seekers. The core idea of ensuring such informational assistance is to prepare potential migrants for what is expected of them in Sweden, especially taking into consideration that their expectations may not be met in reality. A significant nexus within the task force is the Migration Agency, an implementing institution responsible for asylum procedures and one of the most direct platforms providing information for refugees in reception centers (Pamment, 2017).

The Swedish Institute is one of the most significant institutions responsible for managing the image of Sweden. It has become engaged in the task force on migration efforts and it is one of the most active actors managing Sweden's image in the context of the refugee crisis. The crisis forced new initiatives to be undertaken by the Swedish Institute and NSU in order to tackle the problem of the potential worsening of Sweden's image abroad as a result of the refugee crisis. On the platform www.swedes.se, a new short promotional film This Is Sweden was published. The film shows different ways of seeing Sweden: generous parental leave, same-sex marriages, quality, innovativeness, sustainability, equality and ethnic diversity, the specifics of the seasons in Sweden, and tourist attractions (Swedish Institute, This Is Sweden). This is one of the tools used by Sweden to communicate its core values to the outside world and accentuate all of the positive aspects of the Swedish society and nation.

The platform www.sweden.se is also used in other ways to manage Sweden's image in terms of migration. The phenomenon of migration is highlighted 
here as a process that is strongly related to Sweden. The history of migration to Sweden is introduced. What is interesting is that in the introduction to the Sweden and Migration section, the refugee crisis is mentioned as a challenge for Sweden; however, it is necessary to notice the personal stories of refugees and the general complex reality. The integration issue is highlighted as well, as according to data from 2015, every sixth person in the Swedish population was born outside of Sweden (Statistiska Centralbyrån, 2016). Currently, what disturbs Swedes the most and causes intensified integration debate is the growing number of beggars. Another problem deriving from the refugee crisis is the number of unaccompanied minors seeking asylum. In 2015, 35,000 children reached Sweden without parents or legal guardians, and 6,853 children were granted asylum in 2016. The argument given for restrictions within the asylum policy is to limit immigration and therefore find resources needed for providing for the refugees who have already arrived. Another argument for introducing restrictions is not taking responsibility for the refugee crisis and not fulfilling the agreed shares of refugees by other EU countries (Immigration to Sweden). In this way, Sweden via the Swedish Institute is trying to explain itself and legitimize its decisions regarding the country's asylum and migration policies. This is done using a double-track approach. The first step is to give information concerning migration traditions to Sweden, showing the country's long tradition of being open, tolerant, and caring. The second step seems to be based on admitting that many challenges and difficulties are caused by such an intense refugee inflow and that the country is unable to deal with those challenges on its own. Such a strategy seems to build a new and authentic image of Sweden in which the tradition of humanitarian aid and compassion are still present but have been adjusted to reflect the new reality.

Sweden still wants to be perceived as a country that is ready to support those seeking asylum in spite of the legal changes introduced by the government. One method of such an image policy is to show that Sweden and its government are still open for refugees and recognize their problems, fears, and expectations. In order to show the human face of the refugee crisis, a special project has been introduced called Portraits of Migration. The project encompasses the histories of twenty different people forced to leave their countries and flee to Sweden. They share their stories, reasons for migration, and their journey to Sweden, often describing the trauma they have endured (Portraits of Migration). The idea of showing the refugee crisis and refugees themselves in more human manner is also realized within MIG Talks, which is one of the tools allowing for a discussion 
on migration and the refugee crisis. Additionally, a conference scenario with the same name (MIG Talks) has been elaborated in order to initiate a dialogue about migration and integration. Such a conference event provides an opportunity for exchanging information, experiences, and different perspectives on migration between newcomers, inhabitants, and public actors. There are manuals, discussion templates, communication plans, and visual materials available for those who are interested in organizing such event (www.sharingsweden.se). The Swedish Institute has additionally created a website, www.sharingsweden. se, where public actors can download many different ready-to-use promotional materials, in addition to the MIG Talks materials, that support Sweden's external communication and spread knowledge concerning Sweden abroad. Here, visual materials concerning the brand of Sweden, famous Swedes, society and welfare, tourism, education, sustainability, freedom, innovation, culture, gender equality, creativity, and many others can be found. Within aspects related to migration, special materials needed for organizing the Portraits of Migration exhibition have been prepared by the Swedish Institute. The first exhibition was organized in Tallinn in May 2017 at the Museum of Occupations.

Additional efforts have been undertaken by the Ministry for Foreign Affairs, which first prepared a guideline for public diplomacy in 2012 (Offentlig diplo-

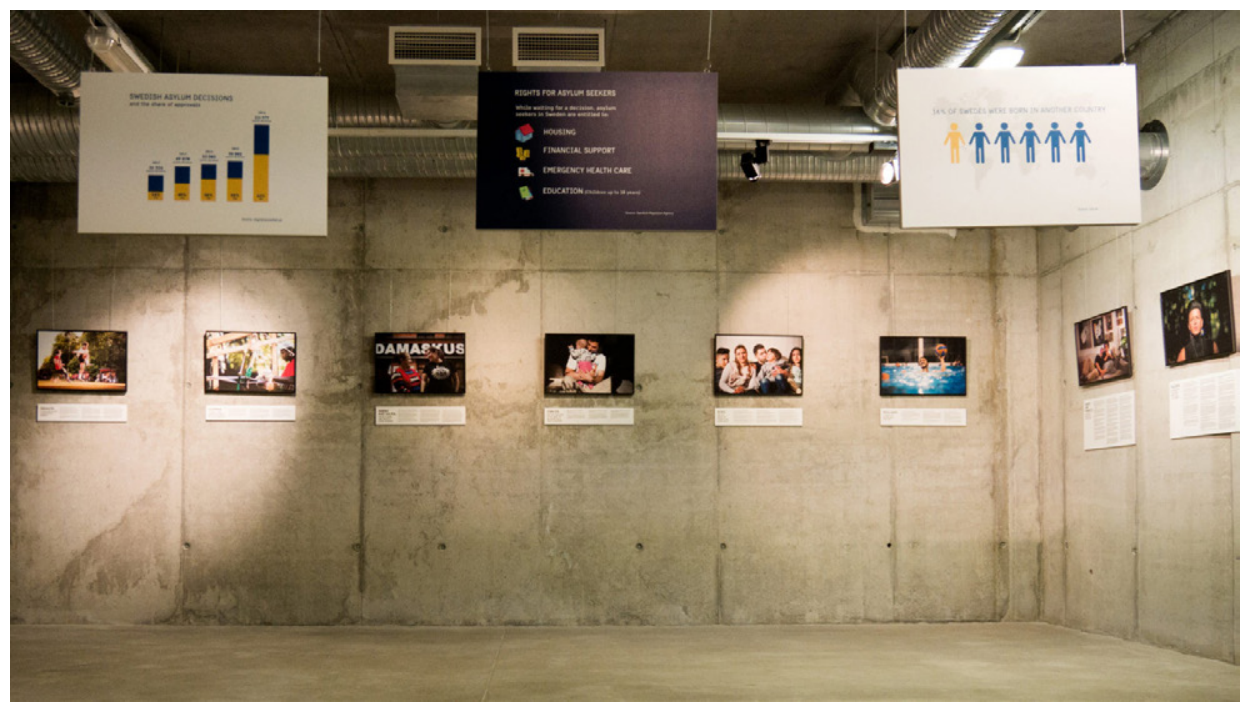

Picture 1. The exhibition at the Museum of Occupations in Tallinn, Estonia Source: www.sharingsweden.se; photo: Mona Loose. 
mati: Vägledning och checklista, 2013), and in 2017 prepared a potential guide including questions concerning communication within public diplomacy, such as the usage of social media, visual identity, and relations with the media (Checklista för kommunikationsfrågor vid utlandsmyndigheterna, 2017).

\section{CONCLUSIONS}

Taking into consideration the considerably long tradition of image policy in Sweden, both in terms of public diplomacy and branding strategies, it is no surprise that the refugee crisis resulted in some changes within Sweden's communication and image patterns. The biggest challenge to Sweden's international image and position seems to be the visible contradiction between the image of Sweden as an open, tolerant, and caring country and the actual steps undertaken by the government through legal changes to its migration and asylum policies.

It is hard to emphasize how and if Sweden's image has changed. Ranking outcomes do not give a clear and explicit answer concerning the current position of Sweden. In some rankings, Sweden's outcome worsened between 2016 and 2017 (Country RepTrak and The Good Country Index), while it remained unchanged in others (Soft Power 30 and Nation Brands Index). Also, a study conducted by the Swedish Institute in 2017 did not show a significant change in respondents' opinions concerning Sweden in light of the refugee crisis. Nevertheless, the topic of migration, integration, and the refugee crisis did occur in the respondents' answers, especially as the topic present in media coverage and therefore one that influences the image of Sweden in the media. Negative way of presenting Sweden in the media and reporting false information concerning the country's domestic situation and suggesting that the polarization of Swedish society and social unrest are growing seem to be the most significant threats to Sweden's brand and reputation.

The country's external image and nation brand have been in construction since the interwar period. They have existed, to a great extent, on the basis of both the welfare state, social justice, tolerance, and openness (Marklund, 2013; Musiał, 2002). Current legal changes within the migration and asylum policies have resulted in - at least partial - closing of this state. Such a situation is contradictory to the branding strategy and the image that Swedes are willing to sustain. As a result, new forms of external communication have been established - a special task force consisting of, among other things, the Swedish Institute, 
new forms and platforms for communicating the current Swedish legal system and its migration and asylum policy, accentuating the human face of migration by organizing informational and social campaigns, and organizing events that provide opportunities for discussing different aspects of migration. All of the changes introduced after the peak of the refugee crisis aimed to explain the reasons for the adjustments made within the migration policy while also accentuating the fact that Sweden was still one of the European states accepting large numbers of refugees. The main improvements in the branding strategy and public diplomacy concerned organizational and institutional changes. The core elements of the branding strategy did not change significantly - the basic values and profile areas stayed unchanged in comparison to the previous branding strategy. What is interesting in the new communication patterns in Sweden is that most of the efforts concentrate mostly on creating tools and mechanisms that are useful for institutions engaged in Sweden's branding or communications process, e.g., embassies. Therefore, ready-to-use promotional materials, instructions, and scenarios for promotional and informative events have been prepared and made available on www.sharingsweden.se for all actors, both public and private, interested in promoting Sweden in a broader sense.

At the same time, it is worth mentioning that the last two branding strategies particularly highlight aspects such as an innovative and creative society while also minimizing the focus on aspects of the welfare state. In an interview with the director of the Department of Intercultural Dialogue at the Swedish Institute, a suggestion was made that Sweden is trying to slightly modify its international profile. According to the Swedish Institute representative, Sweden is mostly associated with its welfare state, the third way or Swedish model, and underestimated in the fields of innovativeness, creativity, and sustainability, which are the new focus areas for the country's branding and communication strategies (Interview, 2017). Such a shift in the elements highlighted in the strategy may suggest that Swedish authorities do not want to focus solely on aspects that are attractive to migrants, especially those connected with the wide social support of the state. Trying to dissemble or at least avoid accentuating aspects that are attractive to migrants may be a very natural method of discouraging them from coming to Sweden or at least limiting immigration. 


\section{ReFERENCES:}

Anholt, S. (2007). Competitive Identity: The New Brand Management for Nations, Cities and Regions. Palgrave Macmillan.

Anholt, S. (2017). The Good Country Index. Retrieved from: https:/goodcountry.org/ index/results.

Anholt-GfK. (2017). Natoin Brands Index. Retrieved from: http://nation-brands.gfk. com.

Chan, S. (2017). 'Last Night in Sweden'? Trump's Remark Baffles a Nation. New York Times. Retrieved from: https://www.nytimes.com/2017/02/19/world/europe/lastnight-in-sweden-trumps-remark-baffles-a-nation.html.

Checklista för kommunikationsfrågor vid utlandsmyndigheterna (2017). Stockholm: Utriketsdepartementet. Retrieved from: http://www.regeringen.se/49e3a4/content assets/4a58eec28f1d4503a11bfc146ce8346b/checklista-for-kommunikationsfragorvidum.pdf?_t_id=1B2M2Y8AsgTpgAmY7PhCfg\%3D\%3D\&_t_q=strategi+för+ sveriges+utvecklingssamarbete\&_t_tags=language $\% 3 \mathrm{Asv} \% 2 \mathrm{Csiteid} \% 3 \mathrm{Ac5}$ a77 4ab-a6e3-4456-8f59-3bde614ae911\&_t_ip=66.249.75.9\&_t_hit.id=RKWeb_Models_Media_PdfFile/_42af4458-95c7-49da-b7ee-995ae2f5720c\&_t_hit.pos=388.

Dinnie, K. (2016). Nation Branding: Concepts, Issues, Practice (2 ${ }^{\text {nd }}$ ed.). London: Routledge.

Eurostat (2017). Asylum Statistics. Retrieved from: http://ec.europa.eu/eurostat/ statistics-explained/index.php/Asylum_statistics.

Government Offices of Sweden (2014). Strategy for the Promotion of Sweden Abroad. Retrieved from: http://sharingsweden.se/wp-content/uploads/2015/06/Sverigefoldern-engelska-i-A5-format.pdf.

Government Offices of Sweden (2017a). Strategy for the Promotion of Sweden Abroad 2.0. Retrieved from: http://sharingsweden.se/wp-content/uploads/2017/09/strategyfor-the-promotion-of-sweden-abroad-2.0.pdf.

Government Offices of Sweden (2017b). Sweden and Immigrants Mostly Get On Well: Opinion Piece by Minister for Justice and Migration Morgan Johansson in Wall Street Journal. Retrieved from: http://www.government.se/opinion-pieces/2017/03/ sweden-and-immigrants-mostly-get-on-well/.

Ham van, P. (2001). The Rise of the Brand State: The Postmodern Politics of Image and Reputation. Foreign Affairs, 80(5), 2-6. DOI: 10.2307/20050245.

Kaneva, N. (2011). Nation Branding: Toward an Agenda for Critical Research. International Journal of Communication, 5, 117-141.

Melissen, J. (2005). The New Public Diplomacy: Between Theory and Practice. In: J. Melissen (ed.). The New Public Diplomacy: Soft Power in International Relations (pp. 3-27). Great Britain: Palgrave Macmillan.

Melissen, J. (2013). Conclusions and Recommendations on Public Diplomacy in Europe. In: M.K.D. Cross \& J. Melissen (eds.). European Public Diplomacy: Soft Power at Work (pp. 205-212). USA: Palgrave Macmillan. 
Migrationsverket (2017). Applications for Asylum Received 2000-2017. Retrieved from: https://www.migrationsverket.se/download/18.4a5a58d51602d141cf41038 /1515076827649/Application\%20for\%20asylum\%20received\%202000-2017.pdf.

Ministry for Justice (2017). Sweden's Migration and Asylum Policy. Retrieved from: http://www.government.se/491b3d/contentassets/26536c43ab3b41df90c064c204 $9 \mathrm{~b} 1 \mathrm{bce} /$ swedens-migration-and-asylum-policy.

Musiał, K. (2002). Roots of the Scandinavian Model: Images of Progress in the Era of Modernisation. Baden-Baden: Nomos Verlagsgesellschaft.

Nye, Jr., J.S. (2004). Soft Power: The Means to Success in World Politics. New York: Public Affairs.

Offentlig diplomati: Vägledning och checklista [Public Diplomacy: Guide and Checklist]. (2013). Stockholm: Utrikesdepartementet/UD-PIK. Retrieved from: http:// www.regeringen.se/49e3a4/contentassets/4a58eec28f1d4503a11bfc146ce8346b/ checklista-for-kommunikationsfragor-vid-um.pdf?_t_id=1B2M2Y8AsgTpgAm Y7PhCfg\%3D\%3D\&_t_q=strategi+för+sveriges+utvecklingssamarbete\&_t_tag s=language\%3Asv\%2Csiteid\%3Ac5a774ab-a6e3-4456-8f59-3bde614ae911\&_t_ ip=66.249.75.9\&_t_hit.id=RKWeb_Models_Media_PdfFile/_42af4458-95c7-49dab7ee-995ae2f5720c\&_t_hit.pos=388.

Olsson, H. (2017). Integrationen fungerar inte som den ska. Dagens Nyheter. Retrieved from: https://www.dn.se/nyheter/politik/integrationen-fungerar-inte-som-denska/.

Pamment, J., \& Wilkins, K.G. (2018). Introduction: New Dimensions in the Politics of Image and Aid. In: J. Pamment, \& K.G. Wilkins (eds.). Communicating National Image Through Development and Diplomacy: The Politics of Foreign Aid (pp. 1-22). Austin: Palgrave Macmillan.

Reputation Institute (2015). 2015 Country RepTrak - Most Reputable Countries. Retrieved from: https://www.reputationinstitute.com/country-reptrak.

Reputation Institute (2016). 2016 Country RepTrak - Most Reputable Countries. Retrieved from: https://www.reputationinstitute.com/country-reptrak.

Reputation Institute (2017). 2017 Country RepTrak - Most Reputable Countries. Retrieved from: https://www.reputationinstitute.com/country-reptrak.

Söderhavet (2014). Global Brand Sweden. Retrieved form: http://soderhavet.com/ uppdrag/sverige/.

Statistiska Centralbyrån (2016). Finland och Irak de två vanligaste födelseländerna bland utrikes födda. Retrieved from: https://www.scb.se/sv_/Hitta-statistik/Artiklar/ Finland-och-Irak-de-tva-vanligaste-fodelselanderna-bland-utrikes-fodda/.

Sveriges Radio (2016). Public Kept in the Dark About Sexual Harassment at Youth Festival. Retrieved from: http://sverigesradio.se/sida/artikel.aspx?programid=205 $4 \&$ artikel $=6342236$.

The Local (2016). Norway's Integration Minister: We Can't Be Like Sweden. Retrieved from: https://www.thelocal.no/20160330/norways-integration-minister-we-cantbe-like-sweden. 
USC Center on Public Diplomacy (2017). Soft Power 30. Retrieved from: https:// softpower30.com.

Witte, G., \& Faiola, A. (2016). Sweden Has Done So Much For Refugees. Now It's Turned Its Back on Them: Sweden Has Taken in More Asylum Seekers Per Capita Than Any Other Nation in Europe. Independent. Retrieved from: http://www.independent. co.uk/news/world/europe/sweden-has-done-so-much-for-refugees-now-itsturned-its-back-on-them-a6792726.html. 